\title{
KEDELAI HITAM (Glycine soja) TERHIDROLISIS SEBAGAI SUMBER FLAVONOID TOTAL
}

\author{
Muammar Fawwaz ${ }^{1}$, Diana Syam Muliadi, A. Muflihunna \\ Fakultas Farmasi, Universitas Muslim Indonesia \\ 1muammar.fawwaz@umi.ac.id
}

\begin{abstract}
Flavonoids are natural phenolic compounds found in almost all plants that have potential as antioxidants. Based on previous research, stating that black soybeans contain compounds of flavonoids. This analysis aims to establish the levels of total flavonoids on ethanol extract of black soybean hydrolyzed. Determination of total flavonoid levels of ethanol extract of black soybean hydrolyzed has been made with UV-Vis spectrophotometry method. Black soybean hydrolyzed using $\mathrm{HCl}$ and extracted using ethanol $70 \%$. The extracts obtained were analyzed qualitative by the method of coloring reaction and quantitative analysis using UV-Vis spectrophotometer, where quercetin is used as a reference standard. Measurements were performed at maximum wavelength of $444.45 \mathrm{~nm}$. The research showed the average level of total flavonoids is $11.83 \mathrm{mgQE} / \mathrm{g}$ extract or $1,163 \%$. In conclusion extract of black soybean hydrolyzed rich of total flavonoids, and it is related to the activity as antioxidant.
\end{abstract}

Keywords: Flavonoid, black soybean, hydrolysis, UV-Vis Spectrophotometry.

\section{PENDAhUluAN}

Di Indonesia jumlah varietas kedelai hitam yang yang dikembangkan sangat minim. Padahal dari segi syarat tumbuh kedelai hitam (Glycine soja) lebih cocok ditanam di 7 daerah tropis. Cikuray dan Merapi merupakan dua varietas unggul kedelai hitam yang memiliki kadar protein cukup tinggi, akan tetapi ukuran bijinya tergolong kecil. Sedangkan pada Mallika, varietas kedelai hitam yang dilepas tahun 2007, memiliki biji kecil $(9,50 \mathrm{~g} / 100 \mathrm{biji})$ dengan kadar protein lebih rendah (37\%) (Ginting E, 2009).

Kedelai hitam memiliki kandungan protein 40,4g/100g dan antioksidan yakni antosianin dan isoflavon. Kandungan total polifenol, flavonoid dan antosianin yang lebih tinggi daripada kedelai kuning, yakni masing-masing $6,13 \mathrm{mg} / \mathrm{g} ; 2,19 \mathrm{mg} / \mathrm{g} ; 0,65$ $\mathrm{mg} / \mathrm{g}$. Isoflavon merupakan antioksidan golongan flavonoid yang biasa terdapat pada kedelai dan memiliki efek bermanfaat pada penderita Diabetes Melitus dengan meningkatkan serum insulin dan komponen insulin pankreas (Mueller, 2012).

Kedelai memiliki kandungan isoflavon (golongan flavonoid) begitu juga kedelai hitam. Isoflavon merupakan suatu zat dalam kedelai yang mempunyai kemampuan sebagai antioksidan serta mencegah terjadinya kerusakan akibat radikal bebas. Kedelai hitam memiliki kandungan antioksidan lebih tinggi dibandingkan kedelai kuning (Dajanta, 2013).

Isoflavon jenis genistein pada kedelai hitam (Glycine soja) sebesar $4.99 \%$ (b/b) pada ekstrak kedelai yang telah mengalami hidrolisis secara enzimatik dengan menggunakan bakteri probiotik Lactobacillus bulgaricus, begitupula penelitian selanjutnya yang menggunakan bakteri Lactobacillus acidophilus diperoleh kadar genistein sebesar 3.46\% (b/b) (Fawwaz, 2014).

Kadar flavonoid total yang tekandung dalam Kedelai hitam sebesar 1,78 mg RE /g yang jelas lebih tinggi dari kadar flavonoid total yang terkandung pada kedelai kuning yaitu sebesar 0,57 mg RE /g (ShunCheng Ren, 2011). Kadar genistein pada ekstrak biji kedelai hitam terhidrolisis sebanyak 6,574\% dan nonhidrolisis sebanyak 3,007\% (Fawwaz, 2016).

Berdasarkan uraian diatas maka dilakukan penelitian mengenai penetapan kadar flavonoid total pada ekstrak etanol kedelai hitam (Glycine soja) terhidrolisis dengan metode spektorofotometri UVVis.

\section{METODE PENELITIAN}

\section{A. Alat dan Bahan}

Alat-alat yang digunakan adalah seperangkat alat gelas (pyrex), magnetic stirrer (As One), mikropipet (Dragon Lab), oven (memmert), seperangkat alat maserasi, spektrofotometer ultraviolet-visible (Thermo Scientific E.201), timbangan analitik (Ohaus), dan timbangan Neraca (Ohaus).

Bahan-bahan yang digunakan pada penelitian ini adalah alumunium foil, aluminium klorida $10 \%$, aquades, $\mathrm{FeCl}_{3}$, ekstrak dari kacang kedelai hitam (Glycine soja), etanol 70\%, etanol 96\%, (p.a, Merch), $\mathrm{HCl} 2 \mathrm{~N}$ (p.a, Merck), kalium asetat $1 \mathrm{M}$ (p.a, Merck), kuersetin (p.a, Merck), dan serbuk magnesium.

\section{B. Pengambilan dan pengolahan Sampel}

Sampel kedelai hitam (Glycine soja) dibersihkan dari kulit ari yang melekat pada kacang kedelai menggunakan air hangat. Setelah dibersihkan, 
sampel kedelai hitam dikeringkan dalam wadah bersih dan dihaluskan, kemudian sampel kedelai hitam (Glycine soja) siap untuk di ekstraksi.

\section{Metode Ekstraksi}

Biji kedelai dihaluskan dan ditambahkan cairan penyari etanol $70 \%$ dengan perbandingan 1:2 $\mathrm{g} / \mathrm{mL}$, hasil campuran ini kemudian dipanaskan pada suhu $90^{\circ} \mathrm{C}$, diaduk secara konstan selama 2 jam. Campuran dipisahkan dari zat terlarutnya menggunakan vakum filter. Filtrat ditambahkan 37\% $\mathrm{HCl}$ hingga $\mathrm{pH}$ campuran mencapai 3. Campuran ini kemudian dipanaskan pada suhu $90^{\circ} \mathrm{C}$, diaduk secara konstan selama 2 jam. Campuran selanjutnya ditambahkan aquades dengan perbandingan 1:1 $\mathrm{mL} / \mathrm{mL}$ dan diaduk secara konstan pada suhu kamar. Endapan yang terbentuk dipisahkan menggunakan vakum filter. Hasil endapan yang diperoleh kemudian disimpan didalam Freezer (Zhang, 2007).

\section{Analisis Kualitatif Flavonoid}

Sebanyak $100 \mathrm{mg}$ ekstrak ditambahkan etanol $96 \%$. Kemudian dipanaskan. Lapisan atas dipipet dan ditambahkan dengan $\mathrm{HCl}$ pekat $2 \mathrm{~N}$ dan serbuk Mg. Flavonoid: terbentuknya warna merah menunjukkan adanya senyawa flavonoid (Ditjen POM, 1989).

Sebanyak 1 gram sampel diekstraksi dengan menggunakan pelarut etanol $96 \%$. Larutan yang dihasilkan diambil sebanyak $1 \mathrm{~mL}$ larutan uji, kemudian ditambahkan 2 tetes larutan $\mathrm{FeCl}_{3}$. Terbentuknya warna hijau atau hijau biru menunjukkan adanya senyawa flavonoid dalam bahan (Harbone, 1987).

\section{E. Analisis Kuantitatif Flavonoid}

1. Pembuatan Kalium asetat $1 \mathrm{M}$

Ditimbang sebanyak 0,982 gram Kalium asetat kemudian dilarutkan dengan air suling hingga $10 \mathrm{~mL}$.

\section{Pembuatan Aluminium klorida $10 \%$}

Ditimbang sebanyak 1 gram Aluminium klorida kemudian dilarutkan dengan air suling hingga $10 \mathrm{~mL}$.

3. Pembuatan Larutan Stok Kuersetin

Ditimbang sebanyak $10 \mathrm{mg}$ kuersetin kemudian dilarutkan dengan etanol $96 \%$ hingga 10 $\mathrm{mL}$ (1000 ppm). Kemudian dipipet sebanyak 0,5 mL dan dicukupkan dengan etanol $96 \%$ hingga $5 \mathrm{~mL}$ (100 ppm). Kemudian dilakukan beberapa pengenceran lagi dengan beberapa seri konsentrasi.

Untuk membuat konsentrasi 6 ppm, 8 ppm, $10 \mathrm{ppm}, 12 \mathrm{ppm}$, dan $14 \mathrm{ppm}$ masing-masing larutan stok dipipet $0,4 \mathrm{~mL}, 0,5 \mathrm{~mL}, 0,6 \mathrm{~mL}$ dan $0,7 \mathrm{~mL}$, lalu dicukupkan dengan etanol $96 \%$ sampai volume akhir $5 \mathrm{~mL}$ (Chang et al., 2002).

4. Penentuan $\lambda_{\text {maks }}$

Panjang gelombang maksimum kuersetin dilakukan dengan running larutan kuersetin pada range panjang gelombang 400-600nm. Absorbansi maksimum yang diperoleh pada panjang gelombang tertentu merupakan panjang gelombang maksimum kuersetin.

\section{Pengukuran larutan standar kuersetin}

Pada seri konsentrasi 6 ppm, 8 ppm, 10 ppm, $12 \mathrm{ppm}$, dan $14 \mathrm{ppm}$ masing-masing dipipet sebanyak $1,5 \mathrm{~mL}$ dan ditambahkan dengan $1,5 \mathrm{~mL}$ etanol $96 \%$, $0,1 \mathrm{~mL}$ larutan $\mathrm{AlCl}_{3} 10 \%$, dan 0,1 Kalium asetat 1 $\mathrm{M}$, kemudian dicukupkan hingga $5 \mathrm{~mL}$ aquades dan didiamkan selama 30 menit pada suhu ruangan. Ukur serapan pada panjang gelombang serapan maksimum $444,45 \mathrm{~nm}$, dengan larutan blanko campuran $1,5 \mathrm{~mL}$ etanol $96 \%, 0,1 \mathrm{~mL} \mathrm{AlCl}_{3}$ dan $0,1 \mathrm{~mL}$ Kalium asetat, selanjutnya dihomogenkan dan dicukupkan dengan aquades hingga 5,0 $\mathrm{mL}$. Kemudian dibuat kurva baku dan didapatkan persamaan garis lurus (Chang et al., 2002).

\section{Pentapan Kadar Flavonoid Total}

Kandungan flavonoid total ditentukan sesuai dengan prosedur Chang (2002) menggunakan kuersetin sebagai standar referensi. Ditimbang ekstrak Kedelai terhidrolisis $5 \mathrm{mg}$ dilarutkan dalam etanol 96\% hingga $5 \mathrm{~mL}$ (1000 ppm). Larutan uji (1,5 $\mathrm{mL}$ ) ditambahkan dengan $1,5 \mathrm{~mL}$ etanol $96 \%, 0,1 \mathrm{~mL}$ Aluminium klorida 10\%, 0,1 mL Kalium asetat $1 \mathrm{M}$, dan di cukupkan hingga $5 \mathrm{~mL}$ dengan aquades, kemudian diinkubasi selama 30 menit pada suhu ruangan. Selanjutnya, absorbansi sampel tersebut diukur pada panjang gelombang 444,45 nm. Larutan dibuat dalam 3 kali replikasi sehingga kadar flavonoid yang di peroleh didapat sebagai ekuivalen kuersetin/g ekstrak. 


\section{HASIL DAN PEMBAHASAN}

\section{A. Hasil Penelitian}

Tabel 1. Hasil Analisis Kualitatif ekstrak etanol kedelai hitam terhidrolisis

\begin{tabular}{cccc}
\hline Sampel & Pereaksi & Warna & Ket \\
\hline $\begin{array}{c}\text { Ekstrak Etanol } \\
\text { Kedelai Hitam } \\
\text { Terhidrolisis }\end{array}$ & Serbuk $\mathrm{Mg}+\mathrm{HCl}$ pekat & Merah & $(+)$ \\
\hline
\end{tabular}

Keterangan:

$(+)=$ Menunjukkan adanya flavonoid

Tabel 2. Hasil penetapan kadar flavonoid total \% (b/b) pada ekstrak etanol kedelai hitam terhidrolisis.

\begin{tabular}{cccccc}
\hline Replikasi & $\begin{array}{c}\text { Absorbansi } \\
(\mathbf{y})\end{array}$ & $\begin{array}{c}\text { Kandungan } \\
\text { Flavonoid total } \\
\text { awal } \\
(\mathbf{m g} / \mathbf{L})\end{array}$ & $\begin{array}{c}\text { Kandungan Total } \\
\text { Flavonoid } \\
(\mathbf{m g Q E} / \mathbf{g} \\
\text { Ekstrak) }\end{array}$ & $\begin{array}{c}\text { Rata-rata } \\
\text { Kandungan } \\
\text { Flavonoid total } \\
\mathbf{m g Q E} / \mathbf{g}\end{array}$ & $\begin{array}{c}\text { \% Kadar } \\
\text { Flavonoid }\end{array}$ \\
\hline 1 & 0,474 & 11.9444 & 11,485 & & $1,1837 \%$ \\
3 & 0,496 & 12,5555 & 11,8448 & 11,8317 & \\
\hline
\end{tabular}

\section{B. Pembahasan}

Kedelai hitam adalah salah satu tanaman yang dapat digunakan sebagai obat berasal dari genus Glycine. Tumbuhan ini mempunyai peranan yang sangat penting dalam budaya Asia baik sebagai makanan, minuman maupun sebagai obat. Khasiat yang memiliki kadar protein cukup tinggi, akan tetapi ukuran bijinya tergolong kecil.

Sebagian besar kandungan Flavonoid total dalam kedelai hitam ataupun jenis-jenis lain dari produk olahan kedelai hitam terdapat dalam bentuk glikosida yang berkonjugasi dengan mengikat satu molekul gula. Untuk menarik senyawa aglikon yang terkandung dalam kacang kedelai hitam perlu dilakukan ekstraksi hidrolisis. Pada penelitian ini metode ekstraksi hidrolisis yang digunakan adalah cara kimia dengan menggunakan salah satu bahan kimia yaitu asam $(\mathrm{HCl})$ yang dapat mengurai glikosida menjadi glikon dan aglikon.

Kacang kedelai hitam yang sudah halus ditimbang sebanyak 125 gram. Kemudian sampel ditambahkan cairan penyari etanol $70 \%$ dengan perbandingan 1:2 $\mathrm{g} / \mathrm{mL}$, agar sampel terendam semua. Pelarut etanol dapat menembus semua jaringan tanaman untuk menarik senyawa aktif keluar dari jaringan sel sampel, etanol tidak menyebabkan pembengkakan pada membrane sel dan memperbaiki stabilitas bahan terlarut. Proses ekstraksi ini dipanaskan pada suhu $90^{\circ} \mathrm{C}$, diaduk secara konstan selama 2 jam untuk menarik senyawa kimia dari sampel secara sempurna. Campuran dipisahkan dari zat terlarutnya menggunakan vakum filter.

Filtrat ditambahkan $37 \% \mathrm{HCl}$ hingga $\mathrm{pH}$ campuran mencapai 3 untuk mengurai glukosa menjadi aglikon. Campuran ini kemudian dipanaskan pada suhu $90^{\circ} \mathrm{C}$, diaduk secara konstan selama 2 jam. Campuran selanjutnya ditambahkan aquadest dengan perbandingan 1:1 $\mathrm{mL} / \mathrm{mL}$ dan diaduk secara konstan pada suhu kamar. Pada saat ditambahkan aquades, campuran langsung berubah menjadi keruh keputihan yang menandakan proses hidrolisis berhasil, dimana komponen glikon larut dalam air sementara aglikon tidak larut sehingga membentuk endapan. Endapan yang terbentuk dipisahkan menggunakan vakum filter. Kemudian hasil endapan di simpan didalam Freezer. Dari proses tersebut diperoleh berat ekstrak kedelai terhidrolisis sebanyak 1,5975 gram dengan rendamen sebanyak $1,278 \%$. Rendamen merupakan persentase bagian bahan baku yang dapat digunakan atau dimanfaatkan dengan total bahan baku. Rendamen yang semakin besar menandakan bahwa bahan baku tersebut memiliki peluang untuk dimanfaatkan lebih besar dibandingkan bahan baku yang memiliki nilai rendamen rendah atau kecil.

Uji kualitatif dilakukan untuk mengetahui komponen kimia pada tanaman dengan menggunakan reaksi warna dengan pereaksi tertentu. Uji flavonoid ekstrak etanol kedelai hitam terhidrolisis dilakukan dengan dua pengujian yaitu: pertama, diujikan dengan serbuk $\mathrm{Mg}$ ditambahkan beberapa tetes $\mathrm{HCl}$ pekat, 
terbentuk warna merah. Kedua, diujikan dengan $\mathrm{FeCL}_{3}$ terbentuk warna hijau tua atau hijau kotor. Hasil identifikasi menunjukkan ekstrak kedelai terhidrolisis positif mengandung senyawa flavonoid.

Uji kuantitatif flavonoid total dilakukan dengan menggunakan spektrofotometri UV-Vis untuk mengukur seberapa besar kandungan flavonoid yang terdapat pada ekstrak etanol kedelai terhidrolisis, dimana Flavonoid mengandung sistem aromatis yang terkonjugasi dan dapat menunjukkan pita serapan kuat pada daerah UV-Vis. Pada pengujian Spektrofotometri UV-Vis digunakan larutan standar kuersetin. Yang terlebih dahulu dilakukan running dari panjang gelombang 400-600 nm. Hasil running menunjukkan panjang gelombang maksimal standar baku kuersetin berada pada panjang gelombang 444,45 nm. Alasan digunakan panjang gelombang maksimal dalam pengukuran spektofotometri yaitu karena pada panjang gelombang maksimal memiliki kepekaan maksimal dimana perubahan absorbansi untuk setiap satuan konsentrasi adalah yang paling besar. Selain itu pada panjang gelombang maksimal bentuk kurva absobansi memenuhi hukum Lambert-Beer.

Hukum Lambert-Beer menyatakan hubungan linieritas antara absorban dengan konsentrasi larutan analit dan berbanding terbalik dengan transmitan. Larutan standar kuersetin dibuat dalam beberapa seri konsentrasi yaitu 6 ppm, 8 ppm, 10 ppm, 12 ppm, dan $14 \mathrm{ppm}$. Pada rangkaian seri konsentrasi tersebut, masing-masing ditambahkan 1,5 mL etanol $96 \%$ yang berfungsi sebagai pelarut dan ditambahkan $0,1 \mathrm{~mL}$ aluminium klorida $10 \%$ yang berfungsi untuk memberikan efek batokromik, sehingga reaksi warna yang terbentuk dapat diamati dan dapat diukur pada daerah visible. Kemudian ditambahkan $0,1 \mathrm{~mL}$ kalium asetat $1 \mathrm{M}$, yang berfungsi sebagai penstabil, agar efek batokromik yang telah terjadi dapat dipertahankan. Lalu kemudian dicukupkan dengan penambahan aquades hingga $5 \mathrm{~mL}$, dan diinkubasi selama 30 menit pada suhu ruangan dengan tujuan agar reaksi antara larutan standar kuersetin dan pereaksi dapat berlangsung dengan sempurna. Kemudian diukur masing-masing seri konsentrasi tersebut pada panjang gelombang maksimum 444,45 nm. Hasil absorbansi dari rangkaian konsentrasi yang tercatat kemudian dihasilkan kurva kalibrasi linear kuersetin yaitu y = $0.037 \mathrm{x}+0.039$ dengan nilai koefisien determinasi $\left(\mathrm{R}^{2}\right)$ yang diperoleh sebesar 0.999 (gambar 4).

Begitupula pada pengukuran absorbansi sampel ekstrak etanol kedelai hitam terhidrolisis masing-masing dibuat dalam tiga replikasi, dimana larutan sampel ditambahkan $\mathrm{AlCl}_{3}$ terjadi pembentukan kompleks warna flavonoid dan $\mathrm{AlCl}_{3}$ yang berwarna kuning yang memberikan efek batokromik. Selain itu digunakan pula pereaksi kalium asetat dan aquades sebagai pentabil agar didapat larutan berwarna kuning konstan (gambar 8). Efek batokromik pada sampel diharapkan mampu membuat senyawa falvonoid terdeteksi secara spesifik pada spektrofotometri sehingga hasil pengukuran lebih akurat. Kuvet yang digunakan dalam analisis ini adalah kuvet kuarsa yang terbuat dari silika memiliki kualitas yang lebih baik. Hal ini disebabkan karena kuvet terbuat dari kaca dan plastik yang dapat menyerap UV sehingga penggunaannya hanya pada spektrofotometer sinar tampak (VIS). Cuvet kuarsa biasanya berbentuk persegi panjang dengan lebar 1 $\mathrm{cm}$.

Dari hasil penelitian ini kandungan flavonoid total ekstrak etanol kedelai terhidrolisis adalah 11,638 $\mathrm{mgQE} / \mathrm{g}$ ekstrak, yang berarti tiap berat ekstrak etanol kedelai hitam terhidrolisis terkandung 11,638 mg atau $1,163 \%$ flavonoid yang setara dengan kuersetin.

\section{KESIMPULAN}

Berdasarkan hasil penelitian dan analisis data yang dilakukan dapat disimpulkan bahwa, kadar flavonoid total dari ekstrak etanol kedelai hitam terhidrolisis yaitu 11,638 mgQE/g ekstrak atau 1,163 $\%$.

\section{DAFTAR PUSTAKA}

Astuti, S., 2008. Isoflavon Kedelai dan Potensinya sebagai Penangkap Radikal Bebas. Jurnal Teknologi Industri dan Hasil Pertanian. 13(2): 126-136.

Chang, C., Yang, M., Wen, H., and Chern, J., 2002. Estimation of total flavonoid content in Propolis by two complementary colorimetric methods. Journal of Food and Drug Analisis, 10(3): 178-182.

Cheng, S. R., Liu2, Z. L., Wang, P., 2011. Proximate composition and flavonoids content and in vitro antioxidant activity of 10 varieties of legume seeds grown in China. Journal of Medicinal Plants Research Vol. 6(2), pp. 301-308.

Dajanta, K., Janpum, P. \& Leksing, W. 2013. Antioxidant Capacities, Total Phenolics and Flavonoids in Black and Yellow Soybeans Fermented by Bacillus subtilis: A Comparative Study of Thai Fermented Soybeans (thuanao). International Food Research Journal. Vol. 20 (6): 3125-3132.

Ditjen POM., 1989.Materia Medika Indonesia Jilid $\boldsymbol{V}$. Departemen Kesehatan RI: Jakarta.

Fawwaz, M., Wahyudin, E., Djide, N,M., 2014. The Effect of Isoflavon Soybean (Glycine $\max (\mathrm{L})$ Merill) Fermentation Result by Lactobacillus bulgaricus Toward In Vitro Osteoblast Cell Proliferation, International Journal of PharmTech, ISSN: 0974-4304. 
Fawwaz, M., Akbar. N., Pratama M., Saleh, A and Baits, M. 2016. High Performance Liquid Chromatographic Analysis Of Isoflavones Aglycone In Indonesian Soybean. International Journal of Pharmaceutical Sciences and Research. IJPSR ; Vol. 7(10): 4230-4233.

Ginting, E. dan M.M, Adie., 2007. Sifat fisik dan kimia lima galur kedelai hitam serta kualitas kecap yang dihasilkan. hlm. 495-510.Bogor.

Harbone, J.B., 1987. Metode fitokimia:Penuntun cara modern menganalisa tumbuhan. Terbitan Kedua. Terjemahan Kosasih Padmawinata dan Iwang Soediro. ITB: Bandung.

Mueller. 2012. Soy intake and risk of type 2 diabetes mellitus in Chinese Singaporeans. Soy intake and risk of type 2 diabetes. Eur J nutr.; 51(8): 1022-40. 